\title{
Leadership Behaviour and Work Motivation of Defence Leaders
}

\author{
Dr. Karamvir Sheokand, \\ Assistant Professor IMSAR, MDU
}

\begin{abstract}
This research article investigates leadership behaviour and work motivation of Indian Defence Officers of all the three wings (Army, Air Force and Navy).Present work is a blend of exploratory as well as hypothesis testing study under the survey method of research. The population of the study consisted of officers of all the three wings of Indian defence services This research has devoted more attention to the need for achievement because in every sector of organizational working individuals and group of individuals strive to achieve goals and this need is positively associated with managerial performance and success and that a need for achievement can be developed in aspiring managers. Though, small survey conclusions lack generalizability, the present study does provide certain useful insights into leadership behaviour of Indian defence officers and their motivational orientation.
\end{abstract}

KEY WORDS-Leadership Behavior, Motivation, Incentives, Task Orientation.

\section{INTRODUCTION}

Considerable research over the years have been devoted to trying to determine what makes leaders effective. In practice, good leaders are described as simply having the "right stuff". How does a leader get this "Stuff"? Many Training experts and practicing managers believe that the "Right Stuff" may be a mystery yet can be learned through careful observation. Stated differently can we identify certain characteristics, behaviours or situations that make one form of leadership more effective than another? Three major approaches to leadership studies are presented here. Trait, Behavioral and Situational.

In general, Research findings do not agree on which traits are generally found in leaders. The trait approach to leadership has provided some descriptive insight but has little analytical or predictive value. The Trait approach is still live, but now the emphasis has shifted away from personality traits toward job-related skills. Katz has identified technical, conceptual and human skill needed for effective management.

Although the result of these trait theories are helpful in identifying salient characteristics of leaders, little information has been provided to help predict effective leaders. The list of important leadership traits is endless and grows with each passing year. The cumulative findings over the years have led us to conclude that some traits increase the likelihood of success as a leader, but none of the traits guarantee success.

During the 1950's, limitations of the Trait approach to leadership led the behavioral scientists to focus their attention on actual leader behaviour: What the leader does and how he does it. They wondered if there was something unique in the way that effective leaders behave. This theory is based on the belief that effective leaders used a particular style to lead their subordinates to achieve certain goals, resulting in high productivity and morale. The behavioral theories emphasize on leader effectiveness where as Trait theories emphasize on emergence of individual as a leader.

Many definitions of leadership style were proposed by behavioral scientists. Beginning with over a thousand dimensions, they eventually narrowed the list to two categories that accounted for most of the leadership behaviour: task orientation and employee orientation. Task orientation is the emphasis the leader places on getting the job done by actions such as organizing work, work relationship making decisions and maintaining definite standard of performance. Employee orientation is the emphasis the leader places on interpersonal relations, respect 
DOI: $\underline{10.51386 / 25815946 / \mathrm{ijsms}-\mathrm{v} 4 \mathrm{i} 4 \mathrm{p} 136}$

Volume: 4 Issue: 4

July to August 2021

https://www.ijsmsjournal.org

for employees ideas and regard for their feelings: Two major research efforts were undertaken to investigate the behavioral approach to leadership at Ohio State University and the University of Michigan.

The behavioral theories have has modest success in identifying consistent relationship between leadership behaviour and group performance. Research findings suggest that search for a universally "best" style of leadership is in appropriate to the complexities of modern organisation. Situational factors that influence success or failure must be considered.

\section{WORK MOTIVATION}

Motivation is a process that starts with a physiological or psychological deficiency or need that activates a behavior or a drive that is aimed at a goal or incentive. Thus, the key to understanding the process of motivation lies in the meaning of, and relationship among, needs, drives and incentives.

NEEDS $\longrightarrow$ DRIVES $\longrightarrow$ INCENTIVES

The above figure graphically depicts the motivation process. Needs set up drives aimed at incentives; this is what the basic process of motivation is all about. In a systems sense, motivation consists of these three interacting and interdependent elements:

1 .Needs: Needs are created whenever there is a physiological or psychological imbalance. For example, a need exists when cells in the body are deprived of food and water or when the personality is deprived of other people who serve as friends or companions. Although psychological needs may be based on a deficiency, sometimes they are not. For example, an individual with a strong need to get ahead may have a history of consistent success.

2. Drives: With a few exceptions, drives, or motives (the two terms are often used interchangeably), are set up to alleviate needs. A physiological drive can be simply defined as a deficiency with direction. Physiological and psychological drives are action oriented and provide an energizing thrust toward reaching in incentive. They are at the very heart of the motivational process. The examples of the needs for food and water are translated into the hunger and thirst drives, and the need for friends becomes a drive for affiliation.

3. Incentives: At the end of the motivation cycle is the incentive, defined as anything that will alleviate a need and reduce a drive. Thus, attaining an incentive will tend to restore physiological or psychological balance and will reduce or cut off the drive. Eating food, drinking water and obtaining friends will tend to restore the balance and reduce the corresponding drives. Food, water and friends are the incentives in these examples.

\section{REVIEW OF LITERATURE}

The field of leadership is presently in a state of ferment and confusion .Most of the theories are beset with conceptual weakness and lack strong empirical support .several thousand empirical studies have been conducted on leadership effectiveness, but most of the results are contradictory and inconclusive .This confused state of the field can be attributed in a large part to the disparity of approaches , the narrow focus of most researchers and the absence of broad theories that integrate findings from the different approaches(Yukl,1989)

A part of leadership research in Indian context concerns itself with identifying the dominant orientation (authoritarian democratic)of business leaders. Myers(1960) from his interviews with industrialists, government officials, labour leaders , and managers in both Indian and foreign organizations concludes that barring a few ,most Indian top managers are relatively authoritarian in their relationship with lower management and labour. Similar results have been by Ganguly (1964) in his study of leadership behaviour in a state -owned engineering company. Rangaswamy (1976) in his study of leadership behaviour of 56 top level managers has found that Indian managers are more employee-oriented as compared to their American counterparts. Early researchers such as Meade (1967),Meade and Shittaker(1967) , and Murphy(1953) asserted that because Indian culture ,by and large, is authoritarian, it is authoritarian leadership which would promote organizational productivity in the Indian set- up .But this assertion has lost ground in recent years. A study testing the hypothesis that the supervisory practices 
DOI: $\underline{10.51386 / 25815946 / \mathrm{ijsms}-\mathrm{v} 4 \mathrm{i} 4 \mathrm{p} 136}$

characterized by participative style are more satisfying to employees that those characterized by directive style, was conducted in a teaching and research organization in Ahmadabad .(Saiyadain ,M.S.,1974) the result of the study indicated that a style characterized by flexible, responsive and considerate of needs of subordinates (participative style ) induces greater satisfaction compared to the one which in production oriented ,rigid and inconsiderate of the feelings of the employees. Some evidence is available which seems to be inconsistent with the participative approach but somewhat congruent with the autocratic approach .Sharma(1973) states that the headmasters of openclimate type school were high on initiating structure .Another piece of evidence come from a systematic study by Saiyadain(1974).He has reported that employees high on social competence felt more satisfied with autocratic superiors .Although autocratic supervisors were less rewarding than the democratic ones .These conflicting results ,thus emphasize the need to draw upon familial values in India to set up organizations just as the Japanese have been doing (Ray,1970).

The contingency model of leadership suggests that the leader's effectiveness is determined by the interaction of employee - orientation with three additional variables, namely leader member relations, task structure, and leader position power .Leader member relations are determined by the manner in which the leader is accepted by the group; task structure reflects the degree to which one specific way is required to the job. Leader position power describes the organizational power that is provided for the position the leader occupies.

Hornstein, Heilman, Mone and Tartell (1987) discuss the relationship between behavioural sciences and leadership behaviour.it is suggested that leaders my need to possess different characteristics in different situations. A model of four perspectives on leadership behaviour is presented, which includes trait theories, leadership style theories, trait situation match ,and leadership style /situation match .A number of recent investigations conducted by Setty (1982), Sinha and Sinha (1984), Srivastava and Kumar(1984),Greenspan(1985),Srivastava and Pratap (1985) ,Sinha and Kumar (1986) ,Mumford(1986) Johnson and Snyder(1986), Meindl and Ehrich(1987), and Srivastava (1988) have shown that different leadership situations require different leadership styles.

\section{METHODOLOGY OF RESEARCH:}

\section{(A) The Research Problem and Its Nature:}

The present study has been conducted on officers of Indian Defence. The curiosity to know what motivates Indian Defence personnel and how they behave as leaders in their own settings has been the inspiration for this investigation. It is a data-based study which is non- experimental, comparative and exploratory in nature that could be categorised as a questionnaire-based survey research of defence personnel.

In a non-experimental study, researchers tend to observe, analyse, and describe what exists rather than manipulating the variables under investigation and the essential task of any survey type research is to obtain information from a sample of respondents that relates to the question being studied .The research problem investigated embodies all these characteristics of a survey type research. The study explores self - perceived leadership behavior of defence officers and their motivational orientation based on Herzberg's two factor theory and McClelland's need theory. Three separate instruments have been used to measure leadership behavior and motivational orientation of respondents. Besides discovering a possible relationship between leader effectiveness and work motivation, necessary comparison has been made between motivation and effectiveness. Similarly, certain hypotheses based on Situational Leadership Model (SLM) have also been tested out.

(B) Sample Profile of Respondents:

Around 800 printed questionnaires were distributed randomly to various defence officers of Army, Air Force and Navy located at Jodhpur, Bombay, Ambala,Delhi and Goa. But only 230 filled-in questionnaires were received which became the sample size for the present work. Thus, the response rate has been around $30 \%$. Following is the sample profile of respondents: 
DOI: $\underline{10.51386 / 25815946 / \mathrm{ijsms}-\mathrm{v} 4 \mathrm{i} 4 \mathrm{p} 136}$

Volume: 4 Issue: 4

July to August 2021

https://www.ijssmsjournal.org

SAMPLE PROFILE

\begin{tabular}{|l|l|l|}
\hline Variables & Number of Respondents & Percentage \\
\hline Age group: & & \\
Upto 30 yrs & 67 & 29 \\
$31-40$ yrs & 109 & 47 \\
$41-50$ yrs & 54 & 24 \\
\hline Gender: & & 88 \\
Male & 202 & 12 \\
Female & 28 & \\
\hline Experience: & & \\
Upto 10 yrs & 103 & 44 \\
$11-20$ & 96 & 42 \\
$21-30$ yrs & 31 & 14 \\
\hline Educational Level: & & \\
Graduate & 122 & 53 \\
Post graduate & 108 & 47 \\
\hline
\end{tabular}

\begin{tabular}{|l|l|l|}
\hline Educational Discipline: & & \\
Arts & 67 & 29 \\
Science & 57 & 24 \\
Commerce & 23 & 10 \\
Engineering & 68 & 30 \\
Management & 11 & 05 \\
Law & 04 & 02 \\
& & \\
\hline Service wing: & & \\
Air Force & 131 & 57 \\
Army & 52 & 23 \\
Navy & 47 & 20 \\
\hline TOTAL & 230 & 100 \\
\hline
\end{tabular}

OBJECTIVES OF THE STUDY:

The following objectives have guided the present investigation:

1. To measure, explore, and analyse motivational needs using pioneering theories of Herzberg and McClelland and making suitable comparisons. 
DOI: $\underline{10.51386 / 25815946 / \mathrm{ijsms}-\mathrm{v} 4 \mathrm{i} 4 \mathrm{p} 136}$

Volume: 4 Issue: 4

July to August 2021

https://www.ijsmsjournal.org

2. Exploring a possible relationship between leader effectiveness and work motivation. This has been done with the help of certain testable hypotheses.

3. Generating certain useful and valid hypotheses on the basis of the findings of the present study.

\section{WORK MOTIVATION}

This paper briefly explains Herzberg's job factors and McClelland's motivational needs of achievement, power, and affiliation. This study includes measurement of Herzberg's job factors and also McClelland's three needs, a conceptual understanding of both the theories is necessary and therefore part one of this chapter is devoted exclusively to Herzberg and Part two devoted explaining the three motivational needs propounded by McClelland.

\section{(I) Herzberg's Job Factors}

Frederick Herzberg (1923-2000), clinical psychologist and pioneer of 'job enrichment', is regarded as one of the great original thinkers in management and motivational theoryFrederick Herzberg's book 'The Motivation to Work', written with research colleagues B Mausner and B Snyderman in 1959, first established his theories about motivation in the workplace. Herzberg's work, originally on 200 Pittsburgh engineers and accountants, has become one of the most replicated studies in the field of workplace psycholog

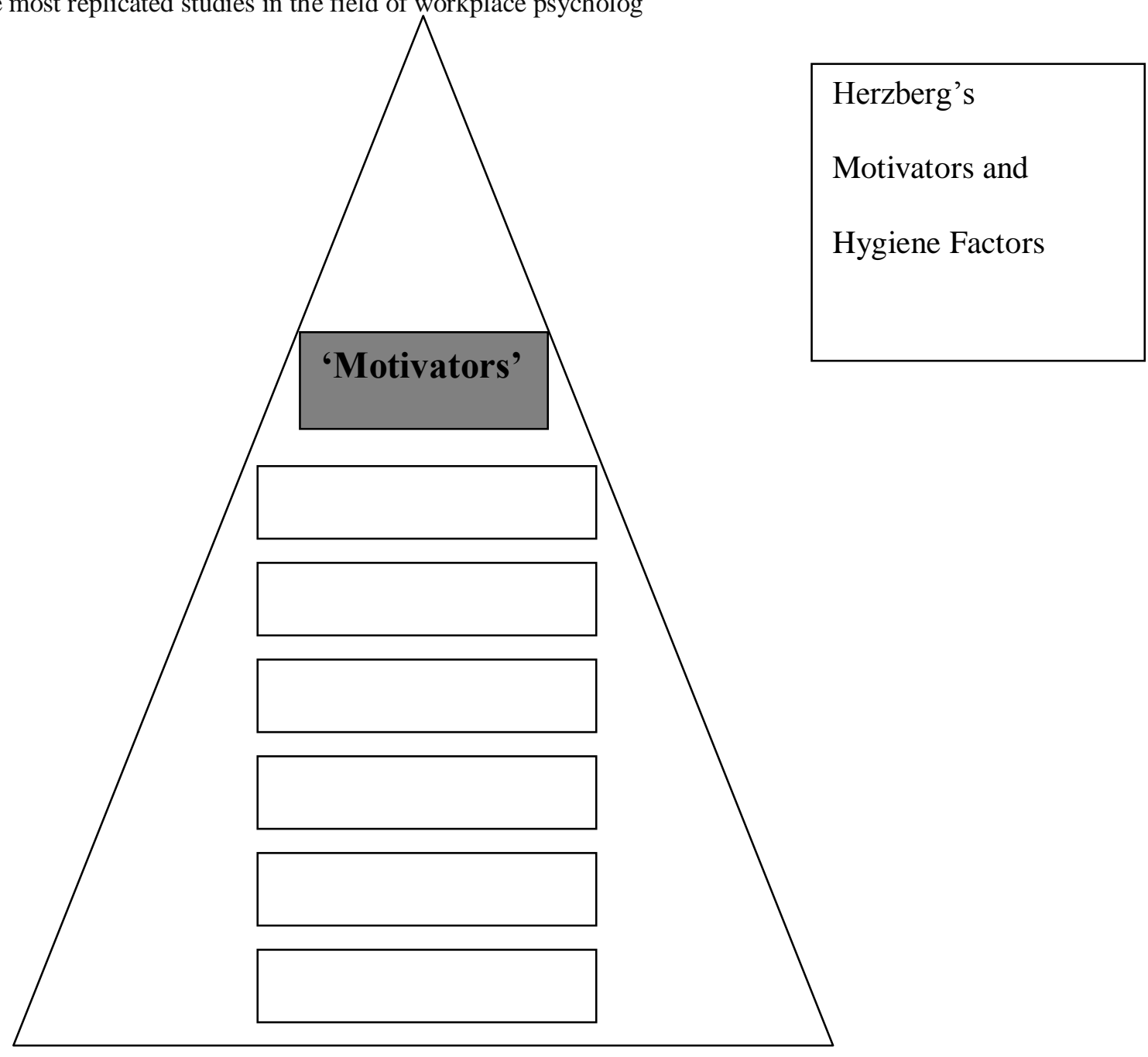


DOI: $\underline{10.51386 / 25815946 / \mathrm{ijsms}-\mathrm{v} 4 \mathrm{i} 4 \mathrm{p} 136}$

Volume: 4 Issue: 4

July to August 2021

https://www.ijsmsjournal.org

Table No.: 1 Hygiene' (or 'maintenance') factors

\begin{tabular}{|l|l|l|}
\hline 'Hygiene' (or 'maintenance') factors & Relationship with subordinates \\
\hline Status & Security & Salary \\
\hline Personal Life & Relationship with peers & \\
\hline \multicolumn{2}{|c|}{ Relationship with supervisors } \\
Work conditions & \multicolumn{2}{|c|}{} \\
\hline \multicolumn{2}{|c|}{ Company policy and administration } & Supervision \\
\hline
\end{tabular}

(II) McClelland's Motivational Needs

American David Clarence McClelland (1917-98) achieved his doctorate in psychology at Yale in 1941 and became professor at Wesleyan University. He then taught and lectured, including a spell at Harvard from 1956, where with colleagues for twenty years he studied particularly motivation and the achievement need. He began his McBer consultancy in 1963, helping industry assess and train staff, and later taught at Boston University, from 1987 until his death. McClelland is chiefly known for his work on achievement motivation, but his research interests extended to personality and consciousness. David McClelland pioneered workplace motivational thinking, developing achievement-based motivational theory and models, and promoted improvements in employee assessment methods, advocating competency-based assessments and tests, arguing them to be better than traditional IQ and personalitybased tests. His ideas have since been widely adopted in many organisations, and relate closely to the theory of Frederick Herzberg.

Volunteers were asked to throw rings over pegs rather like the fairground game; no distance was stipulated, and most people seemed to throw from arbitrary, random distances, sometimes close, sometimes farther away. However a small group of volunteers, whom McClelland suggested were strongly achievement-motivated, took some care to measure and test distances to produce an ideal challenge - not too easy, and not impossible. Interestingly a parallel exists in biology, known as the 'overload principle', which is commonly applied to fitness and exercising, ie., in order to develop fitness and/or strength the exercise must be sufficiently demanding to increase existing levels, but not so demanding as to cause damage or strain. McClelland identified the same need for a 'balanced challenge' in the approach of achievement-motivated people.

McClelland firmly believed that achievement-motivated people are generally the ones who make things happen and get results, and that this extends to getting results through the organisation of other people and resources, although as stated earlier, they often demand too much of their staff because they prioritise achieving the goal above the many varied interests and needs of their people.

Development of the Power Motive and Managerial Performance

\begin{tabular}{|l|l|l|}
\hline Maturity Stage & Motivational Pattern & Effect on management \\
\hline I & $\begin{array}{l}\text { Desire to influence others is low; in this sense } \\
\text { power motivation is low. }\end{array}$ & $\begin{array}{l}\text { Generally not assertive enough to } \\
\text { manage well }\end{array}$ \\
\hline II & $\begin{array}{l}\text { Power motivation expressed in ways having } \\
\text { little to do with others. }\end{array}$ & Not related to managing \\
\hline III (early) & $\begin{array}{l}\text { High power motivation coupled with low } \\
\text { inhibition and low affiliation motivation }\end{array}$ & $\begin{array}{l}\text { The conquistador pattern of the } \\
\text { feudal lord }\end{array}$ \\
\hline III (late) & $\begin{array}{l}\text { High power motivation coupled with high } \\
\text { inhibition and low affiliation motivation }\end{array}$ & $\begin{array}{l}\text { The personalized power shades into } \\
\text { socialized power }\end{array}$ \\
\hline IV & $\begin{array}{l}\text { High power motivation of an altruistic type } \\
\text { coupled with high inhibition and low affiliation } \\
\text { motivation }\end{array}$ & $\begin{array}{l}\text { Selfless leadership and efficient } \\
\text { organizational management }\end{array}$ \\
\hline
\end{tabular}


DOI: $\underline{10.51386 / 25815946 / \mathrm{ijsms}-\mathrm{v} 4 \mathrm{i} 4 \mathrm{p} 136}$

Volume: 4 Issue: 4

July to August 2021

https://www.ijsmsjournal.org

The theoretical relationship between the various types of power motivation and managerial performance are set in table given below. The effective organizational manager begins to emerge in late Stage III with the advent of socialized power motivation (thus the addition of inhibitory tendencies). However, individuals at lower developmental stages may function effectively in some managerial roles.

McClelland (1975) does accept a formulation originally put forth and documented by Litwin and Siebrecht (1967) that for managers who perform in an integrator role, such as project and product managers, a more balanced motivational pattern is desirable, perhaps even with affiliative needs stronger than power needs. Such individuals have little position power and need to work through personal relationships.

\section{ANALYSIS AND INTREPRETATION}

\section{H- 1 Herzberg's Job Factors and Leader Effectiveness- 1 *Statement of hypothesis:}

\section{There is no association between \\ Herzberg's Job Factors and Effectiveness $\left(H_{o}\right)$}

\begin{tabular}{|l|c|c|c|}
\hline \multirow{2}{*}{ Factors } & \multicolumn{2}{|c|}{ Effectiveness } & \multicolumn{2}{c|}{ Total } \\
\cline { 2 - 4 } & Effective & Ineffective & $\mathbf{1 8 1}$ \\
\hline Motivators & 169 & 12 & $\mathbf{0 4 9}$ \\
\hline Hygiene Factors & 043 & 06 & $\mathbf{2 3 0}$ \\
\hline Total & $\mathbf{2 1 2}$ & $\mathbf{1 8}$ & \\
\hline
\end{tabular}

Table 2 : Herzberg and Leadership Effectiveness

\section{Null Hypothesis}

$$
\mathrm{H}_{0}: \mathrm{f}_{\mathrm{o}}-\mathrm{f}_{\mathrm{e}}=\text { Zero }
$$

$f_{o}$ : Observed Frequency

. $\mathrm{f}_{\mathrm{e}}$ : Expected Frequency

Testing of hypothesis at $95 \%$ level of confidence.

The degrees of freedom are 1

Calculated Value of chi-square $\chi^{2}=1.660$;

Critical Value of chi-square $\chi_{0.05}^{2}=3.841$;

Calculated Value $<$ Critical Value

The calculated value of Chi-Square is Less than the critical value of Chi-Square, it is therefore the difference between observed and expected frequency is considered to be insignificant.

Since difference is considered insignificant, the Null hypothesis is accepted.

The acceptation of null hypothesis leads us to conclude that Herzberg's two factor theory and Effectiveness are independent of each other and there stands no-association between them.

* Result of hypothesis:

It is discovered that the Herzberg's job factors have no bearing on Effectiveness of leaders as 'Motivators' and 'Hygiene factors' both have been found to be unrelated with effectiveness.

\section{H- 2 McClelland's Needs and Effectiveness}


DOI: $\underline{10.51386 / 25815946 / i j s m s-v 4 i 4 p 136}$

Volume: 4 Issue: 4

July to August 2021

https://www.ijsmsjournal.org

*Statement of hypothesis:

There is no association between

McClelland's Motivational Needs and Effectiveness $\left(H_{o}\right)$

(f)

\begin{tabular}{|l|c|c|c|}
\hline \multirow{2}{*}{ Motives } & \multicolumn{2}{|c|}{ Effectiveness } & \multirow{2}{*}{ Total } \\
\cline { 2 - 4 } & Effective & Ineffective & $\mathbf{1 5 6}$ \\
\hline \multirow{2}{*}{ Achievement } & 145 & 11 & $\mathbf{0 6 2}$ \\
\hline Power & 057 & 05 & $\mathbf{0 1 2}$ \\
\hline Affiliation & 010 & 02 & $\mathbf{2 3 0}$ \\
\hline Total & $\mathbf{2 1 2}$ & $\mathbf{1 8}$ & \\
\hline
\end{tabular}

Table 3 : McClelland and Effectiveness

Null Hypothesis

$$
\mathrm{H}_{0}: \mathrm{f}_{\mathrm{o}}-\mathrm{f}_{\mathrm{e}}=\text { Zero }
$$

$\mathrm{f}_{\mathrm{o}}$ : Observed Frequency

$\mathrm{f}_{\mathrm{e}}$ : Expected Frequency

Testing of hypothesis at $95 \%$ level of confidence.

The degrees of freedom are 2

Calculated Value of chi-square $\chi^{2}=1.458$;

Critical Value of chi-square $\chi_{0.05}^{2}=5.991$;

Calculated Value < Critical Value

The calculated value of Chi-Square is Less than the table value of Chi-Square, it is therefore the difference between observed and expected frequency is considered to be insignificant.

Since difference is considered insignificant, the Null hypothesis is accepted.

The Acceptation of null hypothesis leads us to conclude that motivational orientation and Effectiveness are independent of each other and there stands no-association between them.

* Result of hypothesis:

Effectiveness analyzed in terms of Motivational needs of the respondents shows that there is no association between them. Motivational needs of leaders have no bearing on effectiveness because they are found to be independent of each other.

\section{CONCLUSION}

Motivation is one of the most exciting topics of interest and research in the field of management and organizational behaviour. It is a problem and organizations keep looking for a solution. Managers continue to search for innovative ways to motivate their employees and a significant proportion of today's workers seem to have no enthusiasm for their work. Many people incorrectly view motivation as a personal trait that is, some have it and others do not. Motivation is the result of interaction of the individual and the situation. Certainly, individuals differ in their basic motivational drive. Motivation is the process by which a manager induces others to work to achieve organizational objectives as a means of satisfying their own personal desires. Motives are conditions internal to an individual that 
DOI: $\underline{10.51386 / 25815946 / i j s m s-v 4 i 4 p 136}$

Volume: 4 Issue: 4

July to August 2021

https://www.ijsmsjournal.org

energize, direct, and determine the intensity of behaviors. They impel a person to engage in certain action. Efforts are the observable result of being motivated. Motivation is a broader term than motive. It covers the entire process by which behavior is energized, sustained or diminished.

McClelland's Theory of Needs was developed by David .McClelland of Harvard University and his associates. In the Research, they identified three higher level needs that organization offers to individuals to satisfy. These needs have been classified as: the need for achievement, the need for power and the need for affiliation. Their research has devoted more attention to the need for achievement because in every sector of organizational working individuals and group of individuals strive to achieve goals and this need is positively associated with managerial performance and success and that a need for achievement can be developed in aspiring managers.

\section{Major Findings}

It has been found that Herzberg's job factors have no bearing on Effectiveness of leaders as 'Motivator' and 'Hygiene factor'both have been found to be unrelated with effectiveness .

Effectiveness analyzed in terms of Motivational orientation of the respondents shows that there is no association between them. Motivational orientation of leaders has no bearing on their effectiveness because the two variables are independent of each other.

Achievement, Power and Affiliation motives have been found to be unrelated with degree of effectiveness exhibited by managerial leaders. This is contrary to the general claim that highly motivated individuals will be highly effective leaders. Thus, motivational profile has no bearing on leader effectiveness.

The study reveals that Herzberg's job factors and McClelland Motivational needs are associated with each other.

\section{REFERENCES AND BIBLIOGRAPHY*}

[1] A Bryman , "Leadership in Organizations", in SR Clegg, C Herdy and WR Nord (eds), Managing Organizations : Current Issues (Thousand Oaks, CA : Sage 1999), P 30.

[2] A. Taylor III, “ Is Jack Smith The Man To Fix GM ?”, Fortune, August 3,1998, PP 86-92.

[3] AA Vicere, "Executive Education : The Leading Edge", Organizational Dynamics, Autumn 1996, PP 67-81, J. Barling, T.Weber and EK Kelloway, "Effects of Transformational Leadership Training on Attitudinal and Financial Outcomes : A Field Experiment", Journal of Applied Psychology, December 1996, PP 827-32.

[4] Ader herman J, Mellen Bergh and Gideon J, "Research Methodology in life, Behavioural and Social Sciences", Sage Publications, London, 1999.

[5] Adrian Davies, "Strategic Leadership : Making Corporate Plan Work", Wood Head Faulkner, New York, 1991. Agarawal Dharam Vira, "Human Relations and OrganisationalBehaviour", Deep and Deep, Delhi, 1988.

[6] AH Eagly and BT Johnson, "Gender \& Leadership Style : A Meta-Analysis”, Psychological Bulletin, September 1990, PP 233-56.

[7] B Nanus, Visionary Leadership (New York : Free Press 1992), P 8.

[8] B Nanus, Visionary Leadership, P 8 .

[9] Charles Farkas, Philippe De Backer and Allen Sheppart, "Maximum Leadership : The World's Top Business Leaders Discuss How They Add Value to Their Companies", Orion Books Ltd, London, 1995.

[10] Chatopadhyay Gouranga P, “OrganisationalCulture : Cultural Roots of Modern Management", Discovery Publications House, Delhi, 1991.

[11] D. Barry, "A Man Who Become More Than a Mayor", New York Times, December 31, 2001, P A1 and E. Pooley, "Mayor of the World", Time December 31, 2001, Jan 7, 2002.

[12] James M. McFillen and Philip M. Podsakoff, "A Coordinated Approach to Motivation Can Increase Productivity," Personnel Administrator, July 1983, PP 46. 
DOI: $\underline{10.51386 / 25815946 / \mathrm{ijsms}-\mathrm{v} 4 \mathrm{i} 4 \mathrm{p} 136}$

Volume: 4 Issue: 4

July to August 2021

https://www.ijsmsjournal.org

[13] JB Cunningham and J Mc.Gregor, "Trust and The Design of Work : Complementary Constructs in Satisfaction and Performance", Human Relations, December 2000, PP 1575-91

[14] Kim-Dong one and Bae Johngseok, "Employment Relations and HRM in South Korea”, Ashgate Publications, Hampshire, 2004.

[15] KS Sheokand- 'Personality and leadership effectiveness of school principles: A study of Haryana',Zenith, International Journal of Multidisciplinary. (2013)

[16] Karamvir Singh Sheokand-'Leadership Behaviour and Effectiveness :A Study of Indian Defence Officers' 42-48, RMS Journal of Management and IT, (2012)

[17] M Sashkin, “The Visionary Leader”, in JA Conger and RN Kanungo (eds) Charismatic Leadership, PP 124-25.

[18] M Sashkin, "The Visionary Leader", PP 128-30 and JR Baum, EA Locke and SA Kirkpatrick, "A Longitudinal Study of the Relation of Vision and Vision Communication to Venture Growth in Enterpreneurial Firms", Journal of Applied Psychology, February 1998, P 43-54.

[19] Norman Richard, "Personal Quest for Methodology", $3^{\text {rd }}$ Edition, Siar Dokumentation, Stockholm, 1975.

[20] Nath, Major General Rajendra PVSM “Military leadership in India”, New Delhi lancer Books 1990

[21] Warren Blank, “The Nine Natural Laws of Leadership”, Amacom, American Management Association, New York, 2000. 